\title{
CULTURAL FACTORS INFLUENCING CELL PHONE ADOPTION IN DEVELOPING COUNTRIES: A QUALITATIVE STUDY
}

\author{
Assion Lawson-Body, University of North Dakota, alawsonbody@business.und.edu \\ Lori Willoughby, Minot State University, Lori.Willoughby@minotstateu.edu \\ Jared Keengwe, University of North Dakota, jared.keengwe@email.und.edu \\ Laurence Mukankusi, University of North Dakota, Imukankusi@business.und.edu
}

\begin{abstract}
Many studies have examined factors affecting IT adoption. But few qualitative studies have been conducted regarding the cultural factors influencing IT adoption in developing countries. The objective of this study is to identify cultural factors influencing cell phone adoption in developing countries in which African cultural heritage plays an important role. Data was collected through interviews involving 28 students, from Haitian Republic, who had just bought cell phones or had more than a year's experience with the cell phone use. Our results show that fatalism, conformism, snobbism, time management and information sharing attitude were found as cultural factors influencing cell phone adoption in Haiti. Hofstede's cultural five dimensions (masculinity-femininity, uncertainty avoidance, power distance, individualism-collectivism, and long-versus short-term orientation) were not found as cultural factors influencing cell phone adoption in developing countries. Also, Rogers' IT adoption factors were not found as substitute to cultural factors affecting cell phone adoption in developing countries.
\end{abstract}

Keywords: Culture, IT Adoption, Cell phone, Developing countries, Developed countries.

\section{INTRODUCTION}

Globalization has led developed countries IT firms to enter developing countries in order to do businesses [13]. A review of the IT adoption and cultural disparity literature suggests that there are factors influencing the IT adoption process that the developed country IT firms did not consider [22]. Two groups of theorists were identified. One group of theorists says that the cultural dimensions influencing IT adoption in developing countries must be aligned with the national culture of Hofstede's theory. Hofstede's [7] defines national culture as the "collective programming of the mind which distinguishes the members of one group or category of people from those of another" [13]. This definition was almost the foundation and the underpinning of many studies involving the concept of national culture. The second group, on the other hand, says that factors influencing IT adoption in developing countries must follow Rogers [16]' theory of IT adoption and diffusion.

Studies regarding Hofstede's national culture dimensions and Rogers' IT adoption theory were conducted in developed worlds with the major countries of focus being the developed countries. Few studies focusing on developing countries were concentrated in Asia, in particular India and China [13]. The lack of studies of factors influencing IT adoption in developing countries is related to the low technology advancement in those countries. The technologies available for those developing countries are very expensive for the population because of the cost of living difference between developed countries and developing ones. Individuals in most developing countries do not have access to the basic IT services needed for a simple Internet access, while many other developed countries are dominated by advanced digital telecommunication systems [4].

The advent of the cell phone technology or mobile device has changed everything. Jin and Ji, [10] divided the cell phone user interface into the graphic user interface and the physical user interface. The graphical user interface refers to the screen that allows users and the cell phone to exchange information through graphic elements such as menu, icon, scroll bar, etc. The physical user interface is about the device's external physical elements such as button, switch, knob, label, etc., that represent what the user can touch and handle in a physical way in order to use the cell phones. In 2004, there were over 1.3 billion cell-phone users in the World [21]. This number is expected to double over the next six years [21]. This growth is due mainly to the deployment of new cell phone towers in developing countries rather than from an increase in cellular access lines in developed countries [21]. The saturation 
of the cell phone markets in developed countries move the competition among the wireless service providers to the developing country markets [21]. The de-regulation of the telecommunications industry facilitates the international expansion of the use of cell phones and has made the market of those developing countries lucrative for developed IT firms [21]. However no research has been conducted regarding the cultural factors influencing cell phone adoption in developing countries, but IT adoption factors for developed countries can't be automatically applied to developing countries because they're different.

The objective of this study is to use IT adoption literature and cultural dimensions theories of developed countries to discover the cultural factors behind the cell phone adoption in developing countries where African cultural heritage plays an important role. The research questions are: what are the cultural factors influencing a cell phone adoption in developing countries which has limited access to technologies and limited financial resources? Are there IT adoption factors specific to developing countries culture?

\section{THEORETICAL FOUNDATIONS}

\section{IT Adoption Theories}

Prior research suggests that the determinants and mechanisms for IT adoption decision may vary from stage to stage during the lifecycle of IS usage which starts usually with initial adoption and moves through subsequent stages of continued usage [12]. In addition to the lifecycle theory, the IT adoption theory such as the theory of planned behavior (TPB) has been used to study IT adoption in the IS arena.

TPB is well-established in the IT field. In the TPB, the individual's decision or behavioral intention to adopt the cell phone technology is dependent of attitude, subjective norm, and perceived behavioral control [15]. According to the TPB, there will be ultimately execution of the behavioral intention [15]. The behavioral intention in this study is the acquisition of the cell phone. The subjective norm is the degree of perceived social pressure that the individual feels to adopt the cell phone. Attitude is perception of the capacity of the individual to afford the cell phone adoption. The perceived behavioral control is how easy or difficult the individual thinks that adoption will be, including potential obstacles.

Rogers [16] and other authors have outlined five factors that influence the IT adoption and innovation process. Those factors are: relative advantage, compatibility, ease of use, triability, and perceived usefulness. Tornatzky and Klein [20] found that relative advantage is an important factor in determining adoption of new innovations. Relative advantage is conceptualized as the level to which an IT innovation is better than its predecessor or previous version. Using the technology adoption theory, Rogers [16] was one of the first authors who introduced compatibility in IT literature, by defining it as the extent to which an innovation is perceived as being consistent with the existing values, past experiences, and needs of potential adopters. Ease of use is the perception of how easy the IT innovation is in order to cope with individual personal daily productivity. Rogers argues that triability indicates the potential adopters who are allowed to experiment with an innovation will feel more comfortable with it. Perceived usefulness is the perception of the innovation's utility and importance in the individual's routine activity [8].

\section{National Culture}

National culture is a multidimensional phenomenon. It has been studied in social science, anthropology, education, psychology, journalism, business, and communication science, etc. Traditionally, many authors have conceptualized national culture in different ways. Even though Hofstede's [7] study has been simultaneously praised and criticized, it remains the most popular and widely used empirically based dimensions of national culture [13]. In the first place, Hofstede [7] identifies four dimensions of national culture: masculinity-femininity, uncertainty avoidance, power distance, and individualism-collectivism. In the later run, Hofstede has revised his previous endeavors and added a fifth dimension called long-versus short-term orientation to form five dimensions.

Masculinity-femininity is the extent to which values such as assertiveness, performance, success, and competition, which most societies associate with the role of men, prevail over values such as the quality of life, personal relationships, and care for the weak which most societies associate with the role of women [7], [18], [13]. 
Uncertainty avoidance is the extent to which people feel threatened by uncertainty and ambiguity and then prefer structured situations over unstructured situations [7], [18], [13]. Power distance is the extent to which power and authority are distributed unequally among people creating a situation where some individuals have low and others have high power or authority [7], [18], [13]. Individualism-collectivism is the extent to which individuals prefer to act on individual goals and needs over those of the collective groups whereas in collectivistic cultures, individuals belong to groups that look after them in exchange for loyalty [7], [18], [13]. Long-versus short-term orientation (Confucian Dynamism) is the extent to which the fostering of virtues is oriented towards future rewards, in particular perseverance and thrift [7], [18], [13].

\section{CASE BACKGROUND}

Haiti, officially the Haitian Republic is a country of the West Indies bordered by Dominican Republic to the east and occupies western third of the island of Hispaniola. The capital of Haiti is Port-au-Prince. The country has about 10 million inhabitants and the population is of African descent. Haiti is a country in the Americas which has a developing market economy. The country presents most of the characteristics of developing countries in the African continent.

Since most of the people who live in Haiti have ancestors originally from African countries, the population shares the same cultural dimensions with countries in Sub-Saharan Africa. But there is also a mix of French and Spanish cultures in Haiti. That mix can be seen in the Haitian language which is Creole. Most of the people who live in French Caribbean countries speak Creole. But French language is still the official language of Haiti.

College and university environments offer one of the best opportunities for the adoption of cell phone technology. Because some Haitian students are professionals and have income, the research was conducted on a group that was composed of Haitian students who had just bought cell phones or had more than a year's experience with the cell phone use.

\section{RESEARCH DESIGN AND PROCEDURES}

\section{Site selection}

One of the authors was invited to teach in Port-au-Prince in Haiti for the French and Canadian Governments International organization named "Francophony" located in the Caribbean Islands (AUF). After obtaining the necessary agreement of the deans of four colleges located in Port-au-Prince in Haiti, we began our qualitative study to find the cultural factors influencing the adoption of cell phone in developing countries. To learn more about the story and to prepare the interviews, to identify the interviewees in order to collect data, the following research methods have been used: visits to the Haitian colleges and universities, meeting with the deans, vice-deans, student organizations and clubs. The results of these investigations and explorations were added to the findings from IT adoption and national culture literature to set up an interview guide, which was used to interview groups of students of the colleges and universities in Port-au-Prince.

One of the first tasks in our research was to identify and select the respondents to the study. Most of the participants would come from the Haitian University network. The focus was on groups of participants from University of Quisqueya, the State University of Haiti, School of Infotronic (ESIH), and University Institute of QuisqueyaAmerica (INUQUA).

One of the researchers worked with the college and university student clubs to develop a list of students who would participate in the study.

The focus was on a diverse group of students with different backgrounds. A series of interviews took place with all selected students over a two-week period. Some students were professionals and some were not. The target population for this study was students who primarily use cell phones in their professional or student activities, and who have appropriate knowledge to understand, and comment on all the interview questions. 
Volume XII, No. 1, pp. 97-105, 2011

\section{Data collection}

In total, twenty eight college students of Haitian universities were asked to participate in the interviews.

One of the researchers went to meet the students individually on their respective campus to conduct the interviews for about one hour. All interviews were face-to-face and were conducted in French. All interviews were taperecorded, and the texts of the interviews were transcribed by our research assistants and entered into Windows Word software. The French transcripts were analyzed. The text units and excerpts were translated in English. Table 1 shows the demographic profile of the students.

Table 1. Demographic profile for all respondents

\begin{tabular}{|l|l|}
\hline \multicolumn{2}{|c|}{ Cell phone use (\%) } \\
\hline Cell Phone user for less than a year & 71 \\
Cell Phone user for more than a year & 29 \\
\hline \multicolumn{2}{|c|}{ Gender (\%) } \\
\hline Female Disciplines of students level (\%) \\
Male & 58 \\
\hline \multicolumn{2}{|c|}{42} \\
\hline Faculty of Law and Economics & 22 \\
Faculty of Medicine and Pharmacy & 20 \\
Faculty of Administration and Management & 31 \\
Faculty of Science and Topography & 17 \\
Faculty of Agronomy and Veterinary & 10 \\
Medicine Age (\%) & 7 \\
\hline \multicolumn{2}{|c|}{ Type of Employment (\%) } \\
\hline Under 20 & 78 \\
21-30 years & 10 \\
31-40 years & 5 \\
Over 40 years & 63 \\
\hline \multicolumn{2}{|c|}{20} \\
\hline Retired Not employed & 17 \\
Government employee & 17 \\
Private sector employee & 30 \\
\hline
\end{tabular}

\section{Content Analysis}

ANALYSIS

A content analysis approach was used to analyze and process the data from the interviews. There are three groups of content analysis theorists. There are the defenders of the hermeneutic-interpretative analysis, the proponents of the empirical-explanatory analysis and the advocates of mixed forms of content analysis. Hermeneutic-interpretative analysis is a scientific procedure by means of which textual material is examined to find its meaning and sense [3], while, the empirical-explanatory theorists use content analysis method as a quantitative procedure by assigning content to specific categories and counting frequencies with the aim of describing the manifest content [3]. The mixed forms authors combined qualitative methods of content analysis and the quantifying content analyses. In this paper, we used the mixed form scientific procedure.

Following the content analysis procedures recommended by the mixed forms group, two judges converted text unit frequencies into numbers. The text units which frequently appear in the transcripts and are related to the concept of culture and IT adoption theory were chosen as a unit of analysis in this study. Actually, the interview data of each student was broken down into meaningful text units. The two judges counted the text units to determine their frequency in each message and group the text units which have approximately the same meanings into factors. 
Volume XII, No. 1, pp. 97-105, 2011

\section{FINDINGS}

Some new cultural factors influencing IT adoption were found:

- fatalism

- snobbism

- time management

- conformism

- information sharing attitude.

Those new factors are specific to African country culture. They are common to individuals like Haitian population whose ancestors are originally from south Sahara in Africa.

Surprisingly, none of the expected factors found support. Factors usually associated with Hofstede's cultural dimensions such as: masculinity-femininity, collectivism/individualism, power distance, uncertainty avoidance, and long-versus short-term orientation were not found. Hofstede's national culture five dimensions are limited to developed countries cultures. But cultural differences may influence cell phone adoption in developing countries. Therefore, a distinction must be made between Hofstede's model and cultural dimensions specific to developing countries. Also, Rogers' IT adoption factors were not found as substitute to cultural factors affecting cell phone adoption in developing countries.

\section{Reliability Test}

The reliability assessment of these findings is conducted using Cohen's kappa (k) coefficient. Cohen's Kappa coefficient is used as a measure of the level of agreement between judges in qualitative studies. Cohen's Kappa coefficient that is greater than 0.65 is acceptable [1]. As shown in Table 2, we found Cohen's kappa reliabilities for the cultural adoption factors ranged from a high of .93 to a low of .87 .

Table 2. Inter-judges reliabilities

\begin{tabular}{|l|l|}
\hline Factors & Cohen’s Kappa (k) \\
\hline Fatalism & .89 \\
\hline Snobbism & .90 \\
\hline Conformism sharing & .91 \\
\hline $\begin{array}{l}\text { Information } \\
\text { attitude }\end{array}$ & .93 \\
\hline Time management & .87 \\
\hline
\end{tabular}

DISCUSSION

\section{Time management}

Perception of time is not the same in all cultural environments. Generally in developed countries cultural environment, time is considered like an asset and limited resources. In developing countries cultural environment, time management does not exist and is not an essence. Activities are performed late or with delay without preoccupation about time management.

In most of those developing countries, individuals look heavy in their work and very slow in their reflex because they do not have the same perception of time management as in their counterpart developed countries. It will take more time to use cell phones by a huge majority of people. Finding the location of the buttons on the cell phone can be an issue [11]. In developing countries, students memorize their textbook without necessary understand their contents. But in developed countries, students are more imaginative because they start using technologies resources, computer games, and Internet at younger age. This is due to the availability of those resources and their lower cost 
when taking into account the individuals living standing. In some developing countries, students use computers the first time in college. In consequences, the time to find cell phone buttons can slow down and hamper many operations or transactions. This will add another level of complexity to time management. The use of cell phones can be cumbersome and time consuming. Instead of being used to manage or save time, the use will produce opposite results.

In most developing countries, using cell phones for texting messages can be problematic because of the difficulty to correlate a button and the three letters associated with it (for example, the letter ' $b$ ' is activated by pressing the number '2' twice) [11]. This mechanism involves a minimum of dynamism and level of understanding that could be difficult to find in developing countries. Individuals in developing countries should not be satisfied with the time management aspect when using mobile device like those in developed countries. This is confirmed by one of the declarations from the interviews:

"I do not read my texting message right away. I do not reply, hear and respond to the voice messages saved on my cell phone right away. I always put off that. I always say I will listen and read my texting another day or another time event if I can currently do it. I keep a pile of messages and texting on my cell phones. I feel sometimes stressful about that because I miss opportunities. I am confused and panic when I noticed that a text message is waiting in my cell phone. I do not know how important or urgent is the message? Using the cell phone becomes cumbersome and time consuming"

\section{Fatalism}

Theory of hopelessness has been used to study fatalism [9]. According to this theory, individuals can develop a pessimistic style of thinking that predisposes them to develop negative beliefs about themselves, the world, and their future. Fatalism is a form of predestination.

IT adoption fatalism derived from the concept of fatalism which is the result of psychological accumulation of hopelessness, worthlessness, meaninglessness, powerlessness, and social despair [14]. Fatalism can impact IT adoption in developing countries. People believe to faith and destiny and that whatever they are accomplishing in their daily life is predestined. Each realization comes from local divinities for those who are not church goers. For all problems individuals should be confronted, the answer must be found in their external locus of control [14]. Morgan et al., [14] used external locus of control to explain fatalism. They linked external locus of control to environmental factors such as racial/ethnic cultural identity.

One of the characteristics of cell phone technology is the capability of identifying a cell phone user's location. While many authors argued that can violate individual privacy and discretion, some other authors keep praising this cell phone capability as a way to protect individuals and the society. The fatalism belief in developing countries should push individuals to under-estimate and under-value the cell phone technology capability. Users should not consider this accomplishment as a factor influencing cell phone adoption. Rather they should keep saying that this accomplishment is realized because of the individual destiny and that the individual is anyway predestined to reach that goal or to find that success. Those people will not consider that criteria when it comes to evaluate factor affecting cell phone adoption because their fatalistic mentality and behavior will force them to believe in local divinities or their fate. A highlight of the interviews explained that:

I believe that all success and failure in my life situations do not have any connection with my own personal views, efforts, resources, and talent. Rather I am predestined to accomplish those things. Saying that the use of the cell phone brings me effectiveness is not sure because anyway, everything I am and I accomplished is written before I was born and that could not put on the cell phone use. My personal realization is beyond my own control because it is predestined.

\section{Conformism}

Conformism may lead to the creation of social norm [2]. Conformism is the tendency of individuals to imitate the most common form of behavior usually derived from their ancestors [6]. Social psychology theorists have been 
demonstrated that ancestors tend to create internal rules for behavior using informal procedures, and that conformity to the views of the majority is a powerful factor in determining adherence to the norm [2]. In some cultural traditions, an individual can conform blindly to the prevailing norm, even though this may sometimes involve taking actions that harm oneself [6]. When an intense aversion to competition becomes a norm like in developing countries, it can contribute to conformism which could not favor innovation. Individuals may fail to realize significant benefits from the use of cell phones because they have been adopted to satisfy cultural traditions rather than personal or organizational productivities. Individuals in such situations behave like their predecessors and ancestors. Conformism tends to favor jealousy and directs individuals to do whatever it takes to block other individuals who do not want to follow the traditions or respect the social norm. Therefore, technology innovation in conformism societies is to reject the traditions and to deny common identity or norms received from the ancestors. The use of cell phones in conformism societies corroborates with defiance. Defiance is a strong form of resistance to the local traditions. It can take the form of dismissing rules, openly challenging rules, and even aggressively attacking the rules [19]. A highlight of the interviews explained that:

It is not because of a cell phone that I will reject my ancestor traditions. I use a cell phone because it is a tool to communicate with another person but the occult or invisible communication I have with my ancestors is very important. Remember that my ancestors did not use that technology in their life or traditions. So how can I communicate with my ancestors or deny the way they lived because I use a cell phone? The use of cell phones could not change my conservatism view when it comes to imitate our traditions.

\section{Information sharing attitude}

Information sharing is the extent to which critical or proprietary information is communicated between two individuals [17]. Cultural differences may be a factor in individual or organizational attitudes towards sharing information [17]. Social network theory has been used to study the concept of information sharing. The theory of social networks stipulates that the efficiency of information sharing depends on the strength of the ties between people who are involved [17]. The interdependence theory also was used to explain information exchange between people or organizations. The interdependence theory posits that individuals will share personal information and resources based on the cultural context which is characterized with the degree of friendship, altruistic attitudes, good citizenship norms, and polite behavior [17].

Information sharing has a high importance in developed countries. In contrast, in developing countries, it is information retention which is a source of power in those societies. Individuals who control the information or have access to the source of the information do not share that with the rest of the community. The sharing of some information consists of threatening the stability of the society. Even though, the society needs that information in order to survive. Some societies discourage information sharing because there are cultural disturbances due to the suspicious between individuals and also due to environmental and societal distrust [17]. The information that is supposed to be shared in order to favor the prosperity or the progress of the society is hidden or becomes a secret. Cell phone technologies have substantially increased the potential for information sharing between individuals [17]. In that circumstance, individuals in developing countries might not adopt cell phones because it allows sharing information the whole community needs to survive. Individuals might not adopt cell phones because of some of their functionalities like texting messages because it allows the sharing of information which contradicts their cultural traditions. This is confirmed by one of the declarations from our interviews:

In fact, the cell phone use in our community today is for personal mystification and egoism. Because of that, people do not want to share all functionalities of the cell phones with other because first they are not comfortable when they see others use the same innovation like them. Second, for some categories of people, the cell phone use must be reserved for them or for only some specific individuals. The sharing of cell phone with other people is conceived like lack of respect and humiliation.

\section{Snobbism}

Behavioral theory used to study snobbism can find its origin in the seminal work of Rae (1834) and Veblen (1922) [5]. According to the seminal work, consumers purchase a conspicuous good in order to advertize their wealth, to 
signal their high income and thereby achieve greater social status [5]. The immediate environment influences the behavior of individuals within a given community. That immediate environment can be limited to the individual's country or international community which interacts with the immediate environment. This implies that individuals' behavior in organizations is influenced by the way they believe in their immediate environment. People in developing countries can be influenced by their counterparts in developed countries because they share the same language. People in developing countries imitate people of developed countries but could not imitate the adoption of IT because of the cost of living difference. However, this is not the case of the use of cell phones.

People have inclined to imitate the members of the highest professional status groups or wealthy or highly educated people, or their children of their immediate environment. Those members of the highest professional status groups adopted luxury cars, gadgets, technologies and cell phones. The lower status groups were oriented towards the use of the same materials and equipments even though it might not benefit them or useful to them. The only satisfaction the lower status groups found by using cell phones is to be able to elevate to the highest professional status groups level. The adoption of the cell phones by the lower groups is about the feeling the cell phones brought to them for using the same IT as the highest status groups. This is confirmed by one of the declarations from our interviews:

"Some students acquire cell phones to imitate the high paid professional groups. Individuals include cell phones in their personal asset and belonging and they feel satisfied for having cell phones because they intentionally put them in the high paid category group. Some students do not have books to study but they do have cell phones because they do not want to be behind. Some students have to ask their family members who live in developed countries to buy them cell phones instead of requesting help to pay their tuition or buy college material. I know friends who do not have a computer home to complete their assignments but they get any new cell phones to show their opulence."

\section{CONCLUSION}

This work reports on the cultural factors affecting cell phone adoption in a developing country. Haitian Republic has been chosen because it has developing market economy and shares the same cultural dimensions with countries in Sub-Saharan Africa. Interview data was collected from 28 students of four Haitian colleges and universities located in Port-au-Prince, the capital of Haiti. Those students had just bought cell phones or had more than a year's experience with the cell phone use.

A review of the culture literature suggests that Hofstede's five cultural dimensions (masculinity-femininity, uncertainty avoidance, power distance, and individualism-collectivism, and long-versus short-term orientation) are the most used to conduct cross-cultural studies. Also, a review of IT adoption literature shows that Rogers' IT adoption theory was the most used to identify factors affecting IT adoption. Starting with the Hofstede's model and Rogers' IT theory, a qualitative study was conducted based on content analysis to discover which of those existing cultural or IT adoption factors can be found to influence a cell phone adoption in Haiti.

The cell phone adoption in Haiti was found to be influenced by cultural factors specific to African population traditions: fatalism, conformism, snobbism, time management and information sharing attitude. Surprisingly Hofstede's five cultural dimensions were not found. Also, Rogers' IT adoption factors: relative advantage, compatibility, ease of use, triability, and perceived usefulness were not found as substitute to cultural factors impacting cell phone adoption in this study.

Lessons from this study recommend that a distinction must be made between cultural dimensions specific to developing countries and Hofstede's model when it comes to adopting IT. This study should allow the IT firms to better understand the high competition challenge among international wireless service providers in developing countries.

\section{REFERENCES}

1. Bahli, B., \& Rivard, S. (2005). Validating measures of information technology outsourcing risk factors. Omega. 33, $175-187$. 


\section{Issues in Information Systems}

Volume XII, No. 1, pp. 97-105, 2011

2. Balestrino, A. (2010). Tax avoidance and the endogenous formation of social norms. The Journal of SocioEconomics. 39, 601-609.

3. Bos, W. Tarnai, C. (1999). Content analysis in empirical social research. International Journal of Educational Research. 31, 659-671.

4. Buys, P., Dasgupta, S., \& Thomas, T. S. (2009). Determinants of a Digital Divide in Sub-Saharan Africa: A Spatial Econometric Analysis of Cell Phone Coverage. World Development. (37:9), 1494-1505.

5. Corneo, G., \& Jeanne, O. (1997). Conspicuous consumption, snobbism and conformism. Journal of Public Economics. 66, 55-71.

6. Guzman R. A., Rodriguez-Sickert, C., \& Rowthorn, R. (2007). When in Rome, do as the Romans do: the coevolution of altruistic punishment, conformist learning, and cooperation. Evolution and Human Behavior. 28, $112-117$.

7. Hofstede, G. (1980). Cultures consequences: International differences in work related values. Beverly Hills, CA: Sage.

8. Hui Min Lee, C., Cheng, Y. W., \& Depickere A. (2003). Comparing smart card adoption in Singapore and Australian universities. Int. J. Human-Computer Studies. 58, 307-325.

9. Jamieson, P. E., \& Romer, D. (2008). Unrealistic Fatalism in U.S. Youth Ages 14 to 22: Prevalence and Characteristics. Journal of Adolescent Health. 42, 154-160.

10. Jin, B. S., \& Ji, Y. G. (2010). Usability risk level evaluation for physical user interface of mobile phone. Computers in Industry. 61, 350-363.

11. Kurniawan, S. (2008). Older people and mobile phones: A multi-method investigation. Int. J. HumanComputer Studies. 66, 889-901.

12. Liao C., Palvia P., \& Chen J-L. (2009). Information technology adoption behavior life cycle: Toward a Technology Continuance Theory (TCT). International Journal of Information Management, 29, 309-320.

13. Malhotra, S., Sivakumar, K., \& Zhu, P. C. (2010). A comparative analysis of the role of national culture on foreign market acquisitions by U.S. firms and firms from emerging countries. Journal of Business Research xxx (2010) $\mathrm{xxx}-\mathrm{xxx}$

14. Morgan, P. D., Tyler, I. D., \& Fogel, J. (2008). Fatalism Revisited, Seminars in Oncology Nursing. (24:4), 237245.

15. Riemenscheinder, C. K., Harrison D. A, \& Mykytyn P. P. (2003). Understanding IT adoption decisions in small business: integrating current theories. Information and Management. 40, 269-285.

16. Rogers, E. M. (1995). Diffusion of innovations (4th ed.). New York, NY: The Free Press

17. Shin, S. K., Ishman, M., \& Sanders, G. L. (2007). An empirical investigation of socio-cultural factors of information sharing in China. Information \& Management. 44, 165-174.

18. Soares, A. M., Farhangmehr, M., \& Shoham, A. (2007). Hofstede's dimensions of culture in international marketing studies. Journal of Business Research, 60, 277-284.

19. Standing, C., Sims, I. \& Love, P. (2009). IT non-conformity in institutional environments: E-marketplace adoption in the government sector. Information \& Management. 46, 138-149.

20. Tornatzky L. G., \& Klein K. J. (1982). Innovation characteristics and innovation adoption-implementation: a meta analysis of findings. IEEE Transactions on Engineering Management. 29(11), 28-45.

21. Turel, O. \& Serenko, A. (2006). Satisfaction with mobile services in Canada: An empirical investigation. Telecommunications Policy. 30, 314-331.

22. Yoon, C. (2009). The effects of national culture values on consumer acceptance of e-commerce: Online shoppers in China. Information \& Management. 46, 294-301. 